\title{
Perceptions of Non-native EFL Teachers' on L1 Use in L2 Classrooms: Implications for Language Program Development
}

\author{
Emre Debreli ${ }^{1}$ \\ ${ }^{1}$ Dr. Fazil Kucuk Faculty of Education, European University of Lefke, Gemikonagi, Turkey \\ Correspondence: Emre Debreli, Dr. Fazil Kucuk Faculty of Education, European University of Lefke, \\ Gemikonagi, Mersin 10, Turkey. Tel: 90-392-660-2660. E-mail: edebreli@eul.edu.tr
}

Received: January 12, 2016

Accepted: February 1, 2016 Online Published: February 2, 2016

doi: 10.5539/elt.v9n3p24

URL: http://dx.doi.org/10.5539/elt.v9n3p24

\begin{abstract}
The study of L1 (first language) use in L2 (second language) classrooms has long received attention in the literature. Despite the considerable amount of research that has been conducted on the phenomenon, the focus has often been on the advantages and disadvantages. Considerably, less research has been conducted regarding the non-native L2 teachers' perceptions of when L1 use is required. More importantly, there has been little research on the limitations faced by non-native EFL (English as a Foreign Language) teachers because of the strong English-only policies they have to follow. The present study explored the perceptions of non-native EFL teachers' towards the existing English-only policies in their institutions. The teachers' perceptions of when L1 should or should not be used in L2 classrooms were also of interest. Fifty-four non-native teachers of EFL from English preparatory schools of four universities in Northern Cyprus participated in the study. Data were collected through semi-structured interviews. Analysis of the data indicated that all of the participating teachers were inclined to use L1 in their L2 classrooms for a variety of reasons. Further, it is found that teachers were affected negatively and were restricted in certain issues as a result of having to follow strict English-only policies at their institutions. Implications for program development are discussed here.
\end{abstract}

Keywords: mother tongue, L1, L2, EFL, non-native teachers

\section{Introduction}

For the last four decades, the discussion on whether to use L1 (first language) when teaching English in foreign language classrooms has been unable to reach a substantial conclusion. Despite strong English-only policies in many language education institutions, a number of scholars have come to realize that appropriate use of L1 might be beneficial for learners (Hawks, 2001). Pessimistic views on the phenomenon seem to center on the idea that "every second spent using the L1 is a second not spent using English! - And every second counts!" (Atkinson, 1993), which often suggests the ban of L1 from L2 (second language) classrooms. Optimistic views, conversely, often take the stance of L1 being a bridge when learning L2 (Briggs, 2001), and opt for its inclusion into L2 classrooms to a certain extent. Many of these discussions, however, neglect the role of language teachers, who seem to bring out new points of views. The majority of those teaching English in today's world are non-native teachers of English, whereas the reverse was true in past decades. Such a change in the demographic profile of English language teachers seems to open new doors in the methodology of teaching. That is to say, many scholars have started to consider the advantages of speaking the same L1 as the students, and have been looking for ways to improve learning and teaching (i.e., explaining difficult concepts using L1 and socializing in the classroom). Due to the long tradition of English-only policies and its obligation-based positive perceptions stemming from the mid-1900s, however, many non-native teachers of English still feel ashamed of using L1 in their classrooms, not because it is not beneficial, but because they view it as a personal failure.

To date, a considerable amount of research has explored L1 use in foreign language classrooms by investigating several classrooms. The main focus of such research, however, has only been on the advantages and disadvantages of L1 use on L2 learning. Instances when the students and the teachers require L1 when learning and teaching L2 have also been another research priority. Predominantly, quantitative methodologies have often been preferred, and it now seems that there is ample, and at the same time superficial, evidence suggesting the advantages of using L1 when teaching English in foreign language classrooms, as well as when the students and the teachers require its use. Considering the substantial pressure of the existing perception on the benefits of 
English-only policies, as well as the obligation to follow English-only policies in many language teaching institutions, however, we have less insight into the teachers' perceptions of using L1 when teaching L2. The issue seems to be more important for non-native teachers, who are likely to have different perceptions of the phenomenon (Schweers, 1999) and which are rarely reported. It is thus believed to be important and necessary to explore in depth the perceptions of non-native English teachers regarding the use of L1, in order to provide deeper insight into any limitations these teachers may face when teaching in a strict English-only environment as in the present context. Exploration of such issues with qualitative methodology is also believed to provide an accurate figure of the limitations faced by the teachers. This might be later used for improving institutional policies and programs along with the findings emerging from the teacher voices, for the sake of healthier teaching, learning, and education.

\subsection{Research on Non-Native Teachers' Views on the Use of L1 in L2 Classrooms}

Despite much of the existing research being particularly concentrated on the benefits of L1 use in L2 classrooms and exploring the instances when teachers tend to use L1 in their classrooms, some of the studies indirectly provided useful findings that can be considered to be the opinions of the teachers. These, however, are mostly about different points of views from different contexts, and research directly focusing on the perceptions of the L2 teachers, particularly with regard to the program policy, is scarce. According to many (e.g., Meyer, 2008; Norman, 2008), use of L1 in L2 classrooms is viewed as an effective tool to decrease students' anxiety and affective concerns. Norman (2008) states that "students are often unresponsive, inattentive, and unwilling to speak in class" (p. 692), but when L1 is used the opposite are true. The majority of the existing studies report that non-native L2 teachers consider that L1 should be used in their classrooms (Burden, 2000; Campa \& Nassaji, 2009; Critchley, 1999; Gulzar, 2010; Kovacic \& Kirinic, 2011). The reasons for using L1 emerging from these studies are also varied. Campa and Nassaji (2009), for example, found that the teachers required L1 to translate complex vocabulary from German (L1) into English (L2) and for checking meanings. Cultural issues were also discussed in German. In the study, however, a novice teacher was found to be more inclined to use L1 than an experienced teacher. This perhaps suggests that a distinction be/is made between teacher experience and their likelihood to use L1. Mahmoudi and Amirkhz (2011) conducted a study in Iranian schools and found that lack of time, type of textbook and parental concerns pushed teachers to use L1 and help students achieve better results in their examinations. The teachers in this study believed that learners learn quicker if L1 was used. The issue of saving time was also a prominent theme in the study of Tang (2002), which was conducted in Chinese English as a Foreign Language (EFL) classrooms. Al-Buraki's (2008) study also revealed that teachers needed to use L1 when giving instructions and explaining new concepts. Sampson (2011), Copland and Neokleaous (2011), and Gulzar (2010) also found that L1 was required by non-native teachers for the purposes of clarification, checking comprehension and classroom socialization. Teachers in some studies (e.g., Burden, 2001) also considered that not using L1 might lead to an unhappy classroom atmosphere. Despite there are considerable number of aspects highlighted in the literature on teachers' views on why they need to use L1 in L2 classrooms, these findings seem to stem from quantitative studies, which do not directly focus on the teachers, but they appear to be interpretations of the findings of the studies which often had a larger scope (i.e., effects of L1 use in L2 classrooms or the extent of L1 use in L2 classrooms). The present study, however, attempts to explore the phenomenon from a narrower perspective, by placing more emphasis on teacher views in more depth, through adopting a qualitative research design, with the intention of obtaining a more fine-grained picture of the teacher views.

In order to gather deeper insight on what actually goes on in EFL classrooms, especially on the part of non-native teachers, the present study is designed to explore the perceptions of the teachers who teach English-only programs. Such exploration is believed to provide information about the limitations and pressures teachers face owing to the programs' English-only principles and whether such obligations affect their teaching. Teachers' opinions on when L1 is required in the classroom are also of interest. It is believed that as teachers are active agents of the classrooms, employing policies and principles designated by the institutions or programs as well as being with the students most of the time, their opinions are crucial and can be used to develop institutional programs further.

\section{Method}

In the present study, a qualitative methodology is adopted to explore the teachers' perceptions of the phenomenon in depth. As suggested by many (e.g., Bryman, 2012; Cohen, Manion, \& Morrison, 2011), qualitative research designs are best suited for gathering data about their opinions, perceptions and thoughts from a specific group of people. Selection of a qualitative research design in the present study is believed to serve this purpose. 


\subsection{Research Questions}

The present study seeks to find answers to the following research questions:

1) What are the teachers' perceptions towards using mother tongue in EFL classrooms?

2) What are the limitations that non-native teachers face regarding teaching in adherence to the English-only policies?

\subsection{Participants}

Fifty-four non-native teachers of English working in English preparatory schools of four universities in Northern Cyprus participated in the study. A review of course documentation obtained suggests that these universities are in touch with approximately 3,000 students who participate in English preparatory schools every year. The teachers who participated in the present study were all Turkish Cypriots with a minimum of three years' of teaching experience. They were teaching English as a foreign language at varying language proficiency levels (i.e., beginner, elementary, pre-intermediate, and intermediate).

\subsection{Data Collection Instruments}

Interviews were used in the present study to obtain detailed data along with the qualitative research design adopted. The reason for choosing this instrument is that issues such as thoughts, perceptions, and opinions are best investigated through oral discussion and meaningful conversation (Kvale, 2007; Bryman, 2012).

\subsubsection{Semi-Structured Interviews}

Of the three popular interview types discussed in the literature (structured, semi-structured, unstructured), the semi-structured interview type was chosen for a variety of reasons. First, semi-structured interviews are widely preferred for their flexibility (Patton, 2002). Second, they allow the researcher to ask follow-up questions as well as to probe further (Kvale, 2007; Cohen, Manion, \& Morrison, 2011). These characteristics enrich the findings and clarify the participants' answers. Third, also along with the conception of the present study, semi-structured interview questions are less likely to make pre-assumptions; therefore, they allow the participants to talk freely without imposition.

\subsection{Data Analysis}

Analysis of the data started with verbatim transcription of the audio-recorded data. This process was followed by repeated reading sessions of the transcribed data for familiarization. The data chunks were then labeled (Cresswell, 2007) and similar labels were identified and collected under more general themes or categories (Miles \& Huberman, 1994). The labels or codes that went together were collected under general categories. The overall process of data analysis included repeated reading and checking of the labels given to the data chunks, and the information that was unrelated to the purpose of the research was removed. The analysis revealed three main categories and sub-categories. During the analysis, great care was taken to avoid imposing on the categories, and the phrases the teachers used in the interviews were used on most occasions (Bryman, 2012).

\section{Findings}

This section presents findings obtained from the 54 non-native teachers of EFL. During the analysis of the data, three main categories (also sub-categories) emerged: non-native EFL teachers' perceptions on allowing the use of L1 in L2 classrooms, non-native teachers' perceptions on not allowing the use of L1 in L2 classrooms, and limitations non-native teachers of EFL face owing to the English-only policies. These, as well as their sub-categories, are explored in the following sections.

\subsection{Non-Native EFL Teachers' Perceptions on Allowing the Use of L1 in L2 Classrooms}

All the 54 teachers participating in the study clearly stated in the interviews that L1 should be used in L2 classrooms, and they also mentioned that it was unavoidable. Many also emphasized the benefits of using L1 in L2 classrooms. Frequently, the instances when L1 should be used in EFL classrooms were given as follows: when giving instructions, when explaining difficult topics, when defining vocabulary, and when socializing in the classroom.

\subsubsection{Giving Instructions}

The majority of the teachers in the study said that, "it is much more effective to give instructions in Turkish." According to them, instructions were crucial in terms of guiding students in the classroom, and once the students misunderstood instructions it was difficult to clarify them later. T14's following comment echoes the majority: 
You must be sure that the students understand what you expect them to do correctly as some activities we do in the classroom take more than 10 minutes, and if they get you wrong from the beginning, that means a 10 -minute loss from your lesson. That's why you have to make sure that they get it right from the beginning and this is more possible if you use their L1 when giving instructions to them.

As can be seen, T14's main concern in the above excerpt is regarding time constraints, and she acknowledges that rather than taking a risk of being misunderstood when using L2, she opts for L1 for better clarification of the instructions.

A considerable number of the teachers also made a classification about the importance of instruction and emphasized when it should be used, for example:

Well it depends on the type of instruction you are going to give. I mean, some instructions are critical, and can be complex depending on the activity or the task. Therefore, I believe L1 is a must in such instances. On the other hand, we have simple tasks which require simple instructions. In such cases, we should stick to L2.

\section{T27}

In the above excerpt, a distinction appears between the type and importance of the instruction. According to T27, it seems that L1 use should be allowed only in circumstances where the instruction need be clearly understood.

\subsubsection{Explaining Difficult Topics}

A popular idea emerging from the data indicated that the teachers preferred the use of $\mathrm{L} 1$ when defining difficult topics or when explaining complex grammatical tasks. This mostly arose from the concern that instead of letting students learn something incorrectly, which would then lead to fossilization, they rather preferred to assist them using their L1. The following two excerpts can be viewed as representative of the overall cohort:

It is very common in language classrooms to see that our learners' errors become fossilized in time as a result of improperly learning, or learning incorrectly at the beginning. It is therefore a must to use L1 in instances when the topic is difficult or complex to teach and learn.

Although the duty of learners' learning English is to understand the input provided to them in English, I don't see it that way. I mean, when they reach a certain level, they should be given input in L2, but until they reach that level, we should guide them in L1 at certain points. Otherwise they might learn things incorrectly.

Both of these excerpts seem to focus on the thought that the students might learn some aspects of the language incorrectly. The main concern of the teachers here in preferring L1 seems to be in making sure that students receive the given input correctly, leading to better learning outcomes in the future.

\subsubsection{Defining New Vocabulary}

Use of L1 when defining new vocabulary was the most prominent topic emerging from the data. During the interviews, all of the teachers referred to this category when emphasizing the need to use L1 and emphasized that it is very difficult to define some vocabulary by only relying on the target language. According to the majority, if the students still seem to have problems in understanding after giving them clues, Turkish should be used, or the students should be given the opportunity to check the Turkish meaning using their dictionaries. T6, for example, stated that, "I don't prefer to insist on English because the term [new vocabulary] is already difficult and they might get it wrong from the clues." As in the previous category, the data related to this category also suggest that the main reason for teachers preferring the use of the L1 was related to the concern that the students may misunderstand the new vocabulary items or the input provided to them.

\subsubsection{Socializing in the Classroom}

One of the rarely discussed issues in the literature emerging from the data was that most of the teachers viewed "socialization in the classroom" as a very important aspect of the learning and teaching process, and they mentioned that such socialization can only be done by "telling jokes" and by having a "good rapport" with the students. They viewed the use of L1 to be crucial in achieving these results. According to many teachers, the reason for this was that the students rarely understood jokes in L2 or that they frequently wanted to use L1 when they were close to the teachers. In order to establish such a rapport, for example, many of the teachers stated that they did not want to "disappoint" students by not using L1. They believed that consistent use of L2 did not help 
to establish good relationships between the teachers and the students and that effective teaching also required such a relationship.

Another reason for the teachers preferring L1 was that it was difficult for the teachers to "socialize" or "to tell jokes" in the classroom in L2 as their language proficiency was insufficient. Cultural and terminological differences between L1 and L2 seemed to be the main difficulty, and the teachers often thought that they were unable to socialize when they used L2. As they viewed socialization as an important element of the classroom, this required $\mathrm{L} 1$ use in some instances.

\subsection{Non-Native EFL Teachers'Perceptions on Not Allowing L1 Use in L2 Classrooms}

One of the most interesting issues revealed in the data was that the majority of the teachers used L1 in several instances during the lesson, and they indicated no strict ban of L1 from their lessons. However, two priorities emerged in the data: L1 use was not intruding on the general pace of the lesson and minimum use of L1 with higher proficiency level students. These are explored in the following sections.

\subsubsection{Not Intruding on the General Pace of the Lesson}

The majority of the teachers who participated in the study mentioned that the large proportion of the lesson should be carried out in L2. Interestingly, none of the teachers opted for full use of L2, and they emphasized the importance of using L1 in particular instances discussed in the previous sections. The main reason for this stems from the idea that languages are best learnt when students are exposed to them often, and teachers seem to keep the practice of L2 in their classrooms to a maximum. The following excerpt is explanatory as well as representative of the overall cohort:

It is very obvious that English is best learnt when one gets exposed to it very often, and since our students' only option to get exposed to English is the classroom, we must provide this opportunity to them. I am not saying that the lessons should be conducted with hundred percent English, but more than two-thirds should be carried out in English.

\subsubsection{Minimum Use of L1 with Higher Proficiency Level Students}

Many teachers in the study made a distinction among the students when it came to the extent of L1 use in classrooms with regard to the levels of the students. Although many allowed the use of L1, some seemed to be stricter with higher-level proficiency students. T4, T21, T25, T37 and T53 were stricter about the use of L1, and they argued that the use of L1 should decrease when the students improved. T37's comment below is representative of that:

With lower level students, it's fine to use some Turkish. But with higher levels, it should be avoided to a great extent as we assume that they understand our instructions, and we believe that they have already acquired adequate skills in the target language as they are at upper levels; so we have to force them more to go further and the way to do this is to decrease the use of L1.

The above excerpt clearly highlights the varying amount of L1 use when teaching different student groups. The reason for this could be that these teachers (T4, T21, T25, T37, and T53) were some of those in the overall cohort who were teaching at higher levels showing that their students were better in understanding the majority of the issues that exist in classrooms, whereas the rest of the teachers were not exposed to students at higher levels.

\subsection{Limitations Faced by Non-Native EFL Teachers Regarding the Existing English-Only Policies}

In this category, two types of limitations emerged as important: teaching plastic lessons and unhappy classroom atmospheres.

\subsubsection{Teaching Plastic Lessons}

One of the issues raised most often by the teachers was the issue of "pretending", "playing", and "not feeling pleasure" when teaching. Many of the teachers in the study mentioned that they either pretend, as if feeling pressure from their teaching, or that they "played" the role of using L2 all the time. According to many of the teachers, an L1 ban from classrooms decreased their and their students' motivation and made lessons "dull". Many also stated that because of such a policy, they did not believe that they performed "fully", "successfully", and "enthusiastically", that such an obligation should not exist, and that the teachers should be given the opportunity to teach in their own way. Some teachers also mentioned that they pretended to only allow L2 use, but that they actually allowed the use of L1. As expected, 42 of the 54 teachers blamed the existing policy and 
stated that it only considered some "old conceptions about L2 teaching”, but neglected teachers' opinions. T18's views in this regard were clear, and echo the majority:

It is us [teachers] who are with the students all day long and it is only us who experience the bad sides of not being able to use L1 in our classrooms. I certainly believe that some policies should exist, but such policies should be developed based on teachers' opinions too. Teaching should not be prescriptive. Otherwise, we only teach to please the administrators and do not feel any pleasure from what we do, as we are kind of restricted in doing certain things.

It seems from the above comment that T18 feels restricted from performing her lessons in her preferred style and that the reason she seems not to enjoy what she is doing may be from feeling that the quality of her teaching is decreasing. For this reason, she seems to blame the existing policy's limitations for the way she teaches, perhaps because of feeling that her opinions were not considered important.

Pretending to be teaching in line with policy was a consistent theme raised by the teachers. This is explained by T9 as:

Although a rule exists that the lessons should be English-only like, this is impossible. Students always ask for this and they are always likely to insist on its use. And I also think that there are instances that the use of L1 is unavoidable. What I often do is, I use it when needed. Although I don't feel comfortable when doing it, I play it as if I am doing it as like what is expected from me.

The above excerpt is crucial in demonstrating the downside of forcing a teacher to teach in a way that she does not prefer, which seems to result in pseudo teaching. It seems that T9 unwillingly prefers to fake her administration and teaches in a way she likes. Although this is probably not something she prefers to do, circumstances seem to push her to do this.

\subsubsection{Unhappy Classroom Atmosphere}

Many teachers in the study emphasized the affective concerns they had because of not being allowed to use L1 in their classrooms. According to them, students always insisted on the use of L1, and the teachers always had to refuse, which then lead to a fall in students' enthusiasm. The majority also believed that this is also reflected in students' performance, as they become unwilling to participate in class on subsequent occasions. One of the teachers (T12) explained this as follows:

I always feel in my classroom that when students keep asking questions in Turkish and if I reply to them in English or if I warn them to speak in "English", they do not participate anymore. This definitely affects my pacing and classroom atmosphere negatively.

The majority of the teachers were also concerned that students do not see them as "friendly", and that such a feeling not only affected students' performance, but also made teachers less effective.

An interesting complaint also emerged, perhaps owing to an external factor. For example, in some of the institutions, students were exposed to more than six teachers throughout the academic year-their class changed every seven or eight weeks when their levels changed. According to some of the teachers, this caused "chaos". The teachers mentioned that when they took over a new class, the students in those classes complained about the new teacher's ban of L1, saying that their old teachers allowed the use of L1. Such occasions caused tensions between the students and the teachers, and caused "bad relationships".

\section{Discussions and Conclusions}

The present study tried to provide a detailed picture of the perceptions of a group of non-native EFL teachers' on L1 use in L2 classrooms, as well as the limitations they faced owing to the strict English-only policies they had to follow. With regard to the first research question posed about non-native teachers' perceptions of L1 use in L2 classrooms, the findings show correlation with those existing in the literature, although illustrating teachers' reasons with more in-depth data. With regards to the second research question on the limitations non-native teachers faced because of the strict English-only policies they had to follow, interesting and new findings seemed to emerge that would enrich the findings in the literature. These are discussed in the following paragraphs.

\subsection{Non-Native EFL Teachers' Perceptions on L1 Use in L2 Classrooms}

In the study, all of the non-native EFL teachers clearly indicated that they are in favor of L1 use in L2 classrooms. This finding is interesting in terms of representing the whole cohort. Although it is in line with the existing findings in general (i.e., Burden, 2000; Campa \& Nassaji, 2009; Gulzar, 2010; Kovacic \& Kirinic, 2011), 
it goes further in terms of the strength of the findings. It seems that none of the cohorts studied fully agreed with the use of L1 in L2 classrooms, perhaps because of other reasons that were not identified in L2 classrooms; may be because of other reasons that were not identified in these studies. It may be that some of the teachers in these studies were native speakers of English so that they had to disagree with L1 use as they did not know the students' L1. Or it may be that they were against L1 use for no particular reason; only believing that an L1 ban is beneficial for the students. The present study also suggests that non-native teachers prefer to use L1 in particular instances such as when giving instructions to the students, which is in line with the findings of Al-Buraki (2008), Copland and Neokleaous (2011), and Sampson (2011), when defining new vocabulary as in Campa and Nassaji (2009), when explaining difficult topics similar to the findings of Copland and Neokleaous (2011), and Gulzar (2010), and for socializing in the classrooms as in Burden (2000).

The instances when the non-native teachers' of EFL did not prefer to use L1 in L2 classrooms were when the students were very proficient at L2 use, and when the teachers did not want the L1 to dominate their lessons' pacing. These findings are similar to those of Kayaoglu (2012), who found that teachers preferred not use L1 with higher levels students, but were inclined to use it at beginner levels. In his study, the teachers' main concern was found to be regarding time saving, that is, the teachers also preferred L1 use when they had time constraints while teaching a topic; and without any differentiation between the levels of the students, they chose to use L1 when they needed to save time. Unlike the study of Kim and Petraki (2009) where the teachers were found to be differentiating the instances when L1 should be used in terms of the language skills (i.e., L1 had no role during writing, but was required when speaking), no sensitivity with regard to the use of L1 when teaching specific language skills were identified.

\subsection{Limitations Non-Native EFL Teachers Face with Regard to English-Only Policies}

One of the main concerns of the present study was to explore the possible limitations for the teachers of following an English-only policy. Although the perceptions identified in earlier sections on allowing the use of L1 in L2 classrooms are likely to tell us the possible difficulties non-native EFL teachers might face while teaching, specifically asking the teachers about the limitations they faced seem to bring interesting findings that are rarely reported. Unexpectedly, the majority of the teachers in the study criticized the existing English-only policies they had to follow, and they accepted the fact that they were not enjoying teaching because of the L1 restrictions. Further, they went beyond and mentioned how they played the role of perceiving L2-only use as effective-just to please their administrators. More importantly, they mentioned how they deceived the administration by pretending they were not using $\mathrm{L} 1$ or allowing its use by the students. The main concern of the teachers seemed to be not teaching in a way that they wanted due to the policy restrictions, and that this affected their teaching quality, as well as the satisfaction they felt from teaching. Another concern was not on being able to establish a positive classroom atmosphere, as neither the students nor the teachers were in favor of full L2 use in classrooms, which often yielded negative relationships in the classrooms, and consequently, less fruitful learning and teaching. One of the main criticisms was also existing language policies not considering teachers' opinions on the phenomenon, and the majority of the teachers believe that their views are of utmost importance because they are the ones implementing the policies in classrooms.

\section{Implications for Program Development}

The present study provided a detailed picture of the difficulties non-native EFL teachers faced as a result of being imposed on to implement an English-only policy while teaching. As being the active agents of the classrooms who carry the weight and responsibility of teaching and learning, the teachers are found to be concerned as if they are not given enough consideration with regard to their thoughts. This seemed to influence their performance of teaching, both affectively and in terms of quality. Teachers' opinions of teaching or how teaching should be is crucially important. Otherwise, teaching would turn to a prescription designed by specific authorities who do not participate in classrooms. What's this then might bring onto the surface is less enthusiastic and less effective teachers, and consequently, less successful learners. It is thus utmost important to consider the teachers' opinions and take into attention what they suggest. This is not to say that every suggestion made by the teachers should be regarded as a new principle, as administrations can also have constraints with regard to the implementation of specific principles. However, the findings emerging from the present study address a considerable gap between what teachers think and what they are imposed to do in classrooms. Despite it is often assumed that the topic of L1 use in L2 classrooms came to a conclusion, whereas it has not, it is perhaps for this reason that many of the language institutions fail to reconsider, or update their policies along with the new findings emerging in the literature. One way of such consideration can be done by taking into account of what teachers think and suggest. Another one could be considering students' thoughts on the phenomenon. Applying a needs analysis for both target groups that is institutional-based would be one way of 
doing this. More considerations can be examining the recent findings in the area, as the recent findings seem to be different than the ones appearing a decade ago, possibly because of the changing demographic profile of the world, English language teachers, and language teaching. Reconsideration, and perhaps an update of the existing policies along with the suggested criteria, is likely to leave less doubts and questions, as well as would increase the satisfaction about the quality of English language education provided.

\section{References}

Al-Buraki, M. (2008). The L1 in young learner classrooms: Teachers' views and practices. Retrieved December 12, 2015, from www.moe.gov.om/Portal/sitebuilder/sites/EPS/English/MOE/.../Ch2.pdf

Atkinson, D. (1993). Teaching monolingual classes. London: Longman.

Briggs, M. (2001). Teacher and student attitudes to English-only \& L1 in the EFL classroom. Unpublished MA thesis, University of Bristol, UK.

Bryman, A. (2004). Social research methods (3rd ed). Oxford, UK: Oxford University Press.

Burden, P. (2000). The use of the students' mother tongue in monolingual English 'conversation' classes at Japanese universities. The Language Teacher, 24(6), 5-10.

Burden, P. (2001). When do native English speakers and Japanese college students disagree about the use of Japanese in the English conversation classroom? The Language Teacher, 25(4), 221-332.

Campa, J., \& Nassaji, H. (2009). The amount, purpose, and reasons for using L1 in L2 classrooms. Foreign Language Annals, 42, 742-759. http://dx.doi.org/10.1111/j.1944-9720.2009.01052.x

Cohen, L., Manion, L., \& Morrison, K. (2011). Research methods in education (7th ed.). New York: Routledge.

Copland, D., \& Neoklueous, G. (2011). L1 to teach L2: complexities and contradictions. ELT Journal, 65(3), 270-280. http://dx.doi.org/10.1093/elt/ccq047

Cresswell, J. (2009). Research design: Qualitative, quantitative, and mixed methods approaches (3rd ed.). Sage Publications, California, US.

Critchley, M. (1999). Bilingual support in English classes in Japan: A survey of student opinions of L1 use by foreign teachers. The Language Teacher, 23(2), 10-13.

Gulzar, M. A. (2010). Code-switching: Awareness about its utility in bilingual classrooms. Bulletin of Education and Research, 32(2), 23-44.

Hawks, A. (2001). Making distinctions: A discussion of mother tongue in the foreign language classroom. Hwa Kang Journal of TEFL, 7, 47-55.

Kayaoglu, N. M. (2012). The use of mother tongue in foreign language teaching from teachers' practice and perspective. Pamukkale University Faculty of Education Journal, 32(2), 25-35. http://dx.doi.org/10.9779/PUJE492

Kin, Y., \& Petraki, M. (2009). Students' and teachers' use of and attitudes to L1 in the EFL classroom. The Asian EFL Journal Quarterly, 11(4), 58-89.

Kovacic, A., \& Kirinic, U. (2011). To use or not to use first language in tertiary instruction of English as a foreign language. $1^{\text {st }}$ International Conference on Foreign Language Teaching and Applied Linguistics, Sarajevo.

Kvale, S. (2007). Doing Interviews. Thousand Oaks, CA: Sage.

Mahmoudi, L., \& Amirkhz, S. (2011). The use of Persian in the EFL classroom- the case of English teaching and learning at pre-university level in Iran. English Language Teaching, 4(1), 135-140. http://dx.doi.org/10.5539/elt.v4n1p135

Meyer, H. (2008). The pedagogical implications of L1 use in the L2 classroom. Maebeshi Kyoai Gakuen College Ronsyu, 8, 147-159.

Miles, M. B., \& Huberman, A. M. (1994). Qualitative data analysis (2nd ed.). Thousand Oaks, CA: Sage Publications.

Norman, J. (2008). Benefits and drawbacks to L1 use in the L2 classroom. Proceedings of the JALT Conference, 691-701.

Patton, Q. (2002). Qualitative research and evaluation methods. Thousand Oaks, Calif: London, Sage. 
Sampson, A. (2011). Learner code-switching versus English only. ELT Journal, 3, 1-11. http://dx.doi.org/10.1093/elt/ccr067

Schweers, C. W. (1999). Using L1 in the L2 classroom. English Teaching Forum, 37(2), 6-9.

Tang, J. (2002). Using L1 in the English classroom. English Teaching Forum, 40(1), 36-43.

\section{Copyrights}

Copyright for this article is retained by the author(s), with first publication rights granted to the journal.

This is an open-access article distributed under the terms and conditions of the Creative Commons Attribution license (http://creativecommons.org/licenses/by/3.0/). 